\title{
INFLUENCE OF CULTIVAR AND FERTILIZATION WITH VERMICOMPOST ON FRUIT QUALITY AND YIELD IN LONICERA SPP.
}

\author{
Ivona Enescu (Mazilu) ${ }^{1,2}$, Mirela Călinescu ${ }^{1^{*}}$, Emil Chitu ${ }^{1}$, Mădălina Butac ${ }^{1}$, Monica Sturzeanu ${ }^{1}$, \\ Mihaela Sumedrea ${ }^{1}$ \\ ${ }^{1}$ Fruit Growing Research Institute Pitesti , Marului Street 402, \\ 117450 Maracineni, Romania \\ ${ }^{2}$ University of Craiova, Al. I. Cuza Street 13, Craiova, Romania
}

\begin{abstract}
This paper aims to study the influence of cultivar and vermicompost (organic fertilizer) treatments on fruit quality traits (fruit weight, flesh firmness, juice $\mathrm{pH}$, chromatic coordinates in CIELab system, chlorophyll fluorescence) and plant productivity on Lonicera caerulea L. The experiment was carried out between 2019 and 2020, at the Research Institute for Fruit Growing Pitesti, Romania. To achieve these, three honeysuckle cultivars ('Cera', 'Loni', and 'Kami') were treated with four fertilizer doses: 0.2, 0.3, 0.75, and $1.0 \mathrm{~L}$ per plant. We found that 'Cera' cultivar was characterized by fruits with the highest weight (0.67 g) and firmness (13.71 units Bareiss HPE-II-FFF), 'Kami' cultivar, had the highest total soluble solids content (17.09 ${ }^{\circ}$ Brix), and 'Loni' was the most productive (33.33 $\mathrm{g}$ per plant). Compared to untreated plants, fertilization with vermicompost in a dose of $0.2 \mathrm{~L}$ per plant increased fruit weight by $14.81 \%$, pH by $9.79 \%$, and fruit production per plant by $36.65 \%$, indicating that fertilization with vermicompost could be used in ecological honeysuckle culture technology.
\end{abstract}

Keywords: ecological nutrition, honeyberry, yield.

\section{INTRODUCTION}

Lonicera caerulea L., belonging to the Caprifoliaceae family, is a perennial shrub native to the Holarctic area. It stands out for its cold resistance, early fruit production, multiple uses of fruits both fresh or frozen, and processed, and last but not least, by fruit taste, nutritional value, and nonnutritive components such as polyphenols (especially anthocyanins and phenolic acids, cyanidin 3 glucoside and chlorogenic acid, according to Auzanneau et al., 2018) with the role of supporting human health. In addition to its antioxidant activity (Auzanneau et al., 2018), fruits have shown the potential to reduce postprandial blood glucose (by inhibitory activity on enzymes involved in carbohydrate degradation according to Podsędek et al., 2014) and lipidemia (Takahashi et al., 2014) The successful exploitation of Lonicera crops depends on the pedoclimatic favourability of the area of interest since the genus has the earliest spring phenology and optimal yields are dependent on adequate cross-pollination via insects. Also, to reach the maximum potential of honeysuckle crops, it is necessary to establish a balanced fertilization plan in terms of dose and composition, adapted to the age of the crop (Tremblay et al., 2019), foliar diagnosis, soil type, and irrigation practices (Barney et al., 2007). 
Most fertilization decisions are made based on growth similarities (shape and size) with blueberry or blackcurrant. Therefore, fertilization with high doses of nitrogen $(\mathrm{N})$, phosphorus $(\mathrm{P})$, and potassium (K) is recommended (Tremblay et al., 2019). Although Gerbrandt, 2015 affirmed that $L$. caerulea is adapted to a wide range of soil $\mathrm{pH}$, Tremblay et al., 2019 found that it prefers slightly acidic soils. Both, alkaline and low $\mathrm{pH}$ soils reduce root biomass. Increasing calcium activity reduces the plant's ability to take up other nutrients such as phosphorus and manganese and acidic soils increase aluminum toxicity and its $\mathrm{N}$ limitation effect (Kerely, 2000; Zhao et al., 2018; Tremblay et al., 2019). On the other hand, administration of $\mathrm{P}$ and $\mathrm{K}$ on nutrient-poor soil did not improve the vegetative growth of honeysuckle plants (Tremblay et al., 2019). High doses of nitrogen reduced root biomass (the root system no need to grow to supplement their absorbent surface if there is plenty $\mathrm{N}$ available, according to Zhang, 2007 and Robinson, 1994) and induced senescence and defoliation in Tremblay et al., (2019) experiment.

Although $\mathrm{N}\left(2-4 \mathrm{~g}_{\text {of }} \mathrm{N}\right.$ plant ${ }^{-1}$ year $\left.^{-1}\right)$ is recommended around the plant collet and under an impermeable plastic mulch (polyethylene) (Gagnon, 2015), Tremblay et al. (2019) states should not use $\mathrm{N}$ fertilizers, at least during the establishment period (to allow the root system development), with $\mathrm{P}$ and $\mathrm{K}$ fertilizers used if considered as necessary, as they did not significantly influence root and overall vegetative growth. Complex fertilizers (macro and micronutrients) containing $\mathrm{N}$ with gradual release prove, therefore, to be the ideal solution for the early fertilization of honeysuckle (Gerbrandt, 2015). It is also recommended to take into account the fact that honeysuckle cultivars respond differently to the doses and chemical form under which fertilizers are administered (Tremblay et al., 2019).

The purpose of this paper is to analyze the influence of the cultivar and dose of organic fertilizer vermicompost on fruit quality and yield in organically grown Lonicera caerulea species.

\section{MATERIALS AND METHODS}

The study was conducted in the experimental field of the Research Institute for Fruit Growing Pitesti. The honeysuckle plantation has a density of 1.905 plants ha $^{-1}(3.5 \times 1.5 \mathrm{~m})$, the crown shape is bush, and is drip irrigated. The influence of three cultivars of honeysuckle ('Loni', 'Cera', and 'Kami') and four compost doses on the fruit quality traits (fruit weight, flesh firmness, juice $\mathrm{pH}$, chromatic coordinates in CIELab system, chlorophyll fluorescence) and yield for plants in the third year (2020) after planting was tested.

A bifactorial experiment of 3 x 5-type (15 treatments) was set up. Each treatment contained 5 plants and was replicated 3 times, resulting in a block design, arranged in rows.

The studied experimental factors are:

A factor, a comparative technological study of different cultivars of honeysuckle, with three levels: $\mathrm{a}_{1}$ - 'Loni' cultivar,

$\mathrm{a}_{2}$ - 'Cera' cultivar,

a3 - 'Kami' cultivar.

B factor, dose of ecologically certified fertilizer (vermicompost) that has been tested on Lonicera spp., with five levels:

$\mathrm{b}_{1}=$ vermicompost (soil application) $0.2 \mathrm{~L} \mathrm{plant}^{-1}$;

$\mathrm{b}_{2}=$ vermicompost (soil application) $0.3 \mathrm{~L} \mathrm{plant}^{-1}$;

$\mathrm{b}_{3}=$ vermicompost (soil application) $0.75 \mathrm{~L} \mathrm{plant}^{-1}$;

$\mathrm{b}_{4}=$ vermicompost (soil application) $1 \mathrm{~L} \mathrm{plant}^{-1}$;

$\mathrm{b}_{5}=$ Unfertilized (control). 
We applied five fertilization treatments, in a single administration, to each of the three cultivars, by spreading them around the plants and incorporating the fertilizer into the soil.

Fruits samples of each $\mathrm{A} \times \mathrm{B}$ factors combination were analyzed for fruit quality determinations: fruit medium mass, the flesh firmness (measured with non - destructive penetrometer QUALITEST HPE, equipped with a $0.10 \mathrm{~cm}$ diameter plunger). Fruit juice was analyzed with Horiba LAQUA pH/ORP/COND Meter D74, equipped with 0030/0040 Horiba pH sensor, and total soluble solids were measured with an electronic refractometer Atago Palette PR32.

The external color of the fruit was measured with a Konica Minolta (Sensing Americas) CR400 colorimeter, using a view angle of $10^{\circ}$, standard illuminant D65, and expressed as $\mathrm{L}^{*}$, $\mathrm{a}^{*}$, and $\mathrm{b}^{*}$, the CIELab color space coordinates. For color measurement, two readings were performed on the equatorial zone of each fruit. Colorimetric coordinate $\mathrm{a}^{*}$ corresponds to the green-red axis, where the negative values measure the greenness and the positive values, the redness; $b^{*}$ corresponds to the blue-yellow axis, where the negative values are related to the color blue, and the positive values with the yellow color. Coordinate $\mathrm{L}^{*}(0=$ black, $100=$ white) measures the luminosity (Conesa et al., 2019).

Chlorophyll fluorescence is a non-invasive measurement of photosystem II (PSII) activity and is a commonly used technique in plant physiology. PSII activity is influenced by biotic and abiotic factors (therefore by fertilizers) and could be a sensitive instrument in studying plant repons to environmental change (Murchie and Lawson, 2013). An increased QY value could be interpreted as fruit immaturity, since, as the fruit ripens, its chlorophyll content decreases. In our experiment chlorophyll fluorescence was measured with FluoroPen FP100 fluorimeter. The yield was appreciated by weighing fruits picked from each plant.

We ran an analysis of variance (ANOVA) on the results using the IBM SPSS 14.0 program and if the ANOVA results were significant, the Duncan Multiple Range test (at $p<0.05$ significance level) was used for determining the treatments having significant differences.

\section{RESULTS AND DISCUSSIONS}

As Table 1. presents, on Lonicera spp., in the third year from planting, fruit mass, flesh firmness, juice $\mathrm{pH}$, total soluble solids (TSS), fruit epicarp colour luminosity ( $\left.\mathrm{L}^{*}\right)$, hue on a green (-) to red $(+)$ axis $\left(\mathrm{a}^{*}\right)$ and hue on a blue $(-)$ to yellow $(+)$ axis $\left(\mathrm{b}^{*}\right)$, chlorophyll fluorescence and fruit yield per plant registered following average values: $0.56 \mathrm{~g}, 10.04$ Bareiss HPE-II-FFF units, 2.48, 15.97 ${ }^{\circ}$ Brix, 10.11, 10.26, 14.17, 0.07, $25.93 \mathrm{~g}$.

Significant differences were observed between the three studied cultivars regarding fruit weight, pulp firmness, juice $\mathrm{pH}$, chlorophyll content, and fruit yield per plant (Table 2 and 4.). At a mean level of the fertilization factor, 'Cera' cultivar produced fruits with the highest mass $(0.67 \mathrm{~g})$, firmness (13.71 Bareiss HPE-II-FFF units), and the lowest juice $\mathrm{pH}$ (2.22). Fruits with the highest TSS content $\left(17.09^{\circ}\right.$ Brix) were harvested from 'Kami' cv., having also the highest value of color brightness (10.88), red pigment content (11.07), and epicarp chlorophyll fluorescence (0.09). 'Loni' cultivar was characterized by the least acidic fruits (juice $\mathrm{pH} 2.74$ ) and the highest fruit production per plant $(33.33 \mathrm{~g})$.

Fertilizer dose significantly influenced the average fruit mass, the juice $\mathrm{pH}$, as well as the fruit production on a plant (Table 3 and 4). Application of vermicompost in a dose of 0.21 plant $^{-1}$, compared with untreated plants, significantly increased fruit average mass (from 0.50 to $0.62 \mathrm{~g}$ ), juice $\mathrm{pH}$ (from 2.39 to 2.58), and fruit yield per plant (from 23.34 to $29.90 \mathrm{~g}$ ). Moreover, although without significant difference compared to the control variant, TSS reached its highest value, 16.54 
Vol. 10, Issue 19, pp. 72-79, 2021

https://doi.org/10.47068/ctns.2021.v10i19.009

Current Trends in Natural Sciences (on-line)

${ }^{\circ}$ Brix. Compared with vermicompost 0.21 plant $^{-1}$, a fertilizer dose of 0.31 plant $^{-1}$ increased fruit yield per plant by increasing the number of fruits and not by increasing fruit weight (Table 3 ).

Table1. Statistic descriptors for berry quality traits and fruit yield per plant (expressed in g) on Lonicera spp. in the third year from planting, Maracineni, Arges County, 2020

\begin{tabular}{|c|c|c|c|c|c|c|c|c|c|}
\hline & $\begin{array}{c}\text { Berry } \\
\text { weight } \\
(\mathrm{g})\end{array}$ & $\begin{array}{l}\text { Pulp firmness } \\
\text { (Bareiss HPE- } \\
\text { II-FFF units) }\end{array}$ & Juice pH & $\begin{array}{c}\text { TSS } \\
\left({ }^{\circ} \text { Brix }\right)\end{array}$ & $\mathbf{L}^{*}$ & $\mathbf{a}^{*}$ & $\mathbf{b}^{*}$ & QY & $\begin{array}{c}\text { Fruit } \\
\text { yield per } \\
\text { plant (g) }\end{array}$ \\
\hline Mean & 0.56 & 9,79 & 2.48 & 15.97 & 10.11 & 10.26 & 14.17 & 0.07 & 25.93 \\
\hline Median & $0.55(\mathrm{a})$ & $9.53(\mathrm{a})$ & $2.44(\mathrm{a})$ & 15.87(a) & 9.41(a) & 9.52(a) & 13.63a) & $0.078(\mathrm{a})$ & 20.35(a) \\
\hline Mode & 0.56 & 6.80 & 2.30 & 15.60 & $8.45(b)$ & 8.55 & 14.94(b) & 0.00 & $16.00(b)$ \\
\hline $\begin{array}{l}\text { Std. } \\
\text { deviation }\end{array}$ & 0.16 & 3.91 & 0.27 & 1.84 & 3.26 & 3.30 & 3.87 & 0.08 & 15.74 \\
\hline Range & 0.94 & 19.00 & 1.40 & 13.87 & 27.50 & 27.88 & 32.26 & 0.42 & 58.89 \\
\hline Minimum & 0.19 & 2.20 & 1.90 & 8.93 & 4.97 & 5.07 & 7.03 & 0.00 & 4.11 \\
\hline Maximum & 1.13 & 21.20 & 3.30 & 22.80 & 32.47 & 32.95 & 39.29 & 0.42 & 63.00 \\
\hline
\end{tabular}

(a) Calculated from grouped data.

(b) Multiple modes exist. The smallest value is shown

Honeysuckle treatment with organic certified fertilizer (vermicompost) 0,75 L plant ${ }^{-1}$ insignificantly decreased fruit firmness (from 10,10 to 9.23 Bareiss HPE-II-FFF units) and significantly increased the epicarp chlorophyll content (QY 0.09) compared to control plants (QY $0.05)$.

Cultivar $\times$ fertilization interaction materialized in the significant influence over the quality traits: fruit mass, juice $\mathrm{pH}$, TSS, chromatic coordinates $\left(\mathrm{L}^{*}, \mathrm{a}^{*}, \mathrm{~b}^{*}\right.$ ) and fruit production per plant (Table 4 and Figures 1 - 12). For 'Cera' cultivar, fertilization with vermicompost 0.21 plant $^{-1}$, resulted in an average fruit mass of $0.750 \mathrm{~g}$ (30.26\% higher compared to the control variant). In addition, 'Cera' cultivar was the only one of the three studied in which the application of vermicompost in the dose of 0.3 l plant $^{-1}$ significantly increased fruit firmness, by $28.21 \%$ compared to the control variant (from 12.23, to control, at 15.68 units). There was also a tendency to increase juice $\mathrm{pH}$ by fertilization, significant in 'Loni' cultivar, which recorded a maximum average value of 2.86 when applying vermicompost 0.751 plant $^{-1}$, by $17.70 \%$ higher compared to control (2.43). Fertilization of 'Kami' cultivar with vermicompost 0.2 plant $^{-1}$ determined the increase of TSS by $12.45 \%$, from 16.87 (in the control variant) to $18.97^{\circ}$ Brix. Unlike 'Kami', the other two cultivars response to fertilization was an insignificant reduction in TSS levels. As Figure 5 presents, fertilization reduced $\mathrm{L}^{*}$ (epicarp color luminosity), $\mathrm{a}^{*}$ and $\mathrm{b}^{*}$ values 'Cera' cv. treated with vermicompost $1 \mathrm{~L} \mathrm{plant}^{-1}$. Contrarily, all three chromatic coordinates increased for 'Loni' cv. (when treated with vermicompost 0.751 plant $^{-1}$ ) and 'Kami' (fertilized with 0.21 plant $^{-1}$ vermicompost dose).

Ecologically certified fertilizer, in a $0.75 \mathrm{~L} \mathrm{plant}^{-1}$ dose, increased chlorophyll fluorescence (QY) by $75.95 \%$ in 'Loni' berries (from 0.079 , in the control, to 0.139 ). The lowest level of photosystem 
Current Trends in Natural Sciences

Vol. 10, Issue 19, pp. 72-79, 2021

https://doi.org/10.47068/ctns.2021.v10i19.009

Current Trends in Natural Sciences (on-line)

ISSN: $2284-953 \mathrm{X}$

ISSN-L: 2284-9521
Current Trends in Natural Sciences (CD-Rom)

ISSN: 2284-9521

ISSN-L: 2284-9521

II activity (QY) was recorded in 'Kami' cultivar, untreated plants (0.00), fertilization having, in this treatment variant, a similar effect, of increasing QY value, in other words, postponing fruit maturity. Also, vermicompost $0.2 \mathrm{~L} \mathrm{plant}^{-1}$ increased 'Loni' yield by $26.25 \%$, compared to the untreated plants of the same cultivar (61.32 compared to $48.57 \mathrm{~g}$ ).

Table 2. Cultivar influence on constant fertilization levels on berries quality traits and fruit yield per plant (FYPP, expressed in g) on Lonicera spp. in the third year from planting, Maracineni, Arges County, 2020

\begin{tabular}{|c|c|c|c|c|c|c|c|c|c|c|}
\hline \multicolumn{2}{|c|}{ Experimental factor } & $\begin{array}{l}\text { Berry } \\
\text { weight } \\
\text { (g) }\end{array}$ & $\begin{array}{c}\text { FF } \\
\text { (Bareiss } \\
\text { HPE-II- } \\
\text { FFF units) }\end{array}$ & $\begin{array}{c}\text { Juice } \\
\text { pH }\end{array}$ & $\begin{array}{c}\text { TSS } \\
\left({ }^{\circ} \text { Brix }\right)\end{array}$ & $\mathbf{L}^{*}$ & $\mathbf{a}^{*}$ & $\mathbf{b}^{*}$ & QY & $\begin{array}{c}\text { FYPP } \\
\text { (g) }\end{array}$ \\
\hline \multirow{3}{*}{ Cultivar } & Cera & $0.67^{\mathrm{a}}$ & $13.71^{\mathrm{a}}$ & $2.22^{\mathrm{c}}$ & $16.30^{\mathrm{b}}$ & $9.75^{b}$ & $9.90^{\mathrm{b}}$ & $13.85^{\mathrm{a}}$ & $0.06^{\mathbf{b}}$ & $28.39^{\mathrm{b}}$ \\
\hline & Loni & $0.47^{\mathrm{c}}$ & $8.97^{\mathbf{b}}$ & $2.74^{\mathrm{a}}$ & $14.72^{c}$ & $9.87^{\mathbf{b}}$ & $9.97^{\mathbf{b}}$ & $13.91^{\mathrm{a}}$ & $0.09^{b}$ & $33.33^{\mathrm{a}}$ \\
\hline & Kami & $0.52^{b}$ & $6.70^{\mathrm{c}}$ & $2.49^{b}$ & $17.09^{\mathrm{a}}$ & $10.88^{\mathrm{a}}$ & $11.07^{\mathrm{a}}$ & $14.92^{\mathrm{a}}$ & $0.04^{\mathrm{a}}$ & $16.07^{\mathrm{c}}$ \\
\hline
\end{tabular}

Different letters within the columns indicate statistically significant differences $(p<0.05)$.

Table 3. Fertilisation treatments influence on constant cultivar levels on berries quality traits and fruit yield per plant (FYPP, expressed in g)on Lonicera spp. in the third year from planting, Maracineni, Arges County, 2020

\begin{tabular}{|c|c|c|c|c|c|c|c|c|c|c|}
\hline \multicolumn{2}{|c|}{ Experimental factor } & $\begin{array}{c}\text { Berry } \\
\text { weight } \\
\text { (g) }\end{array}$ & $\begin{array}{c}\text { FF } \\
\text { (Bareiss } \\
\text { HPE-II- } \\
\text { FFF units) }\end{array}$ & $\begin{array}{c}\text { Juice } \\
\text { pH }\end{array}$ & $\begin{array}{c}\text { TSS } \\
\left({ }^{\circ} \text { Brix }\right)\end{array}$ & $\mathbf{L}^{*}$ & $\mathbf{a}^{*}$ & $\mathbf{b}^{*}$ & QY & $\underset{(\mathrm{g})}{\mathbf{F Y P P}}$ \\
\hline \multirow{5}{*}{$\begin{array}{l}\text { Vermi- } \\
\text { compost } \\
\text { dose }\end{array}$} & Control & $0.50^{\mathrm{b}}$ & $10,10^{\mathrm{a}}$ & $2.39^{\mathrm{c}}$ & 16,49 ab & $10.52^{\mathrm{a}}$ & $10.64^{\mathrm{a}}$ & $14.43^{\mathrm{a}}$ & $0.05^{b}$ & 23.34 bc \\
\hline & 0.2 L plant $^{-1}$ & $0.62^{\mathrm{a}}$ & $9.50^{\mathrm{a}}$ & $2.58^{\mathrm{a}}$ & $16,54^{a}$ & $10.27^{\mathrm{a}}$ & $10.41^{\mathrm{a}}$ & $14.45^{\mathrm{a}}$ & $0.05^{b}$ & $29.90^{\mathrm{a}}$ \\
\hline & $0.3 \mathrm{~L}_{\text {plant }}{ }^{-1}$ & $0.54^{\mathbf{b}}$ & $10.06^{\mathrm{a}}$ & $2.46^{\mathrm{b}}$ & $15,76^{\text {ab }}$ & $9.70^{\mathrm{a}}$ & $9.85^{\mathrm{a}}$ & $13.79^{\mathrm{a}}$ & $0.05^{b}$ & $29.45^{\mathrm{a}}$ \\
\hline & $0.75 \mathrm{~L}_{\text {plant }}{ }^{-1}$ & $0.52^{\mathbf{b}}$ & $9.23^{\mathrm{a}}$ & $2.52^{\mathrm{ab}}$ & $15.71^{\text {ab }}$ & $10.44^{\mathrm{a}}$ & $10.60^{\mathrm{a}}$ & $14.67^{\mathrm{a}}$ & $0.09^{\mathrm{a}}$ & $24.56^{b}$ \\
\hline & $1.0 \mathrm{~L} \mathrm{plant}^{-1}$ & $0.58^{\mathrm{a}}$ & $10.07^{\mathrm{a}}$ & $2.46^{\mathrm{b}}$ & $15.59^{b}$ & $9.73^{\mathrm{a}}$ & $9.88^{\mathrm{a}}$ & $1356^{a}$ & $0.07^{\text {ab }}$ & $22.42^{\mathrm{c}}$ \\
\hline
\end{tabular}

Different letters within the columns indicate statistically significant differences $(p<0.05)$.

Table 4. Cultivar and fertilization simple and interaction effects significance on biological indicators on Lonicera spp. in the third year from planting, Maracineni, Arges county, 2020

\begin{tabular}{|c|c|c|c|c|c|c|c|c|c|c|}
\hline & & $\begin{array}{l}\text { Berry } \\
\text { weight } \\
\text { (g) }\end{array}$ & $\begin{array}{c}\text { FF } \\
\text { (Bareiss } \\
\text { HPE-II- } \\
\text { FFF units) }\end{array}$ & $\begin{array}{c}\text { Juice } \\
\text { pH }\end{array}$ & $\begin{array}{c}\text { TSS } \\
\left({ }^{\circ} \text { Brix }\right)\end{array}$ & $L^{*}$ & $\mathbf{a}^{*}$ & $\mathbf{b}^{*}$ & QY & $\begin{array}{c}\text { FYPP } \\
(\mathrm{g})\end{array}$ \\
\hline \multirow{3}{*}{ Signiff. } & Fertilizer & $* * *$ & n.s. & $* * *$ & n.s. & n.s. & n.s. & n.s. & n.s. & $* * *$ \\
\hline & Cultivar & $* * *$ & $* * *$ & $* * *$ & $* * *$ & n.s. & n.s. & n.s. & $*$ & $* * *$ \\
\hline & $\begin{array}{c}\times \\
\text { Cultivar }\end{array}$ & $* * *$ & n.s. & $* * *$ & * & $* * *$ & $* * *$ & $* * *$ & n.s. & $* * *$ \\
\hline
\end{tabular}

Significance letters and symbols refer to cultivar, fertilizer dose and cultivar $x$ Fertilizer dose effects: $n . s .=$ nonsignificant; $*=$ significant at $p \leq 0.05, * *=$ significant at $p \leq 0.01$, and $* * *=$ significant at $p \leq 0.001$, respectively. 


\section{Current Trends in Natural Sciences}

Vol. 10, Issue 19, pp. 72-79, 2021

https://doi.org/10.47068/ctns.2021.v10i19.009

Current Trends in Natural Sciences (on-line)

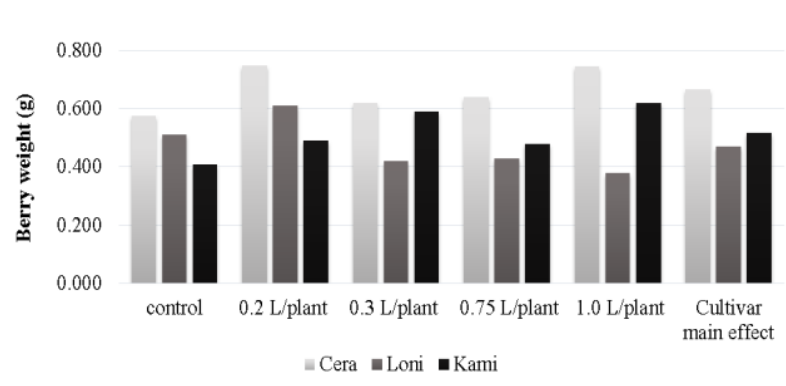

Figure 1. Cultivar influence over berry weight on fertilizer dose levels (Lonicera spp.)

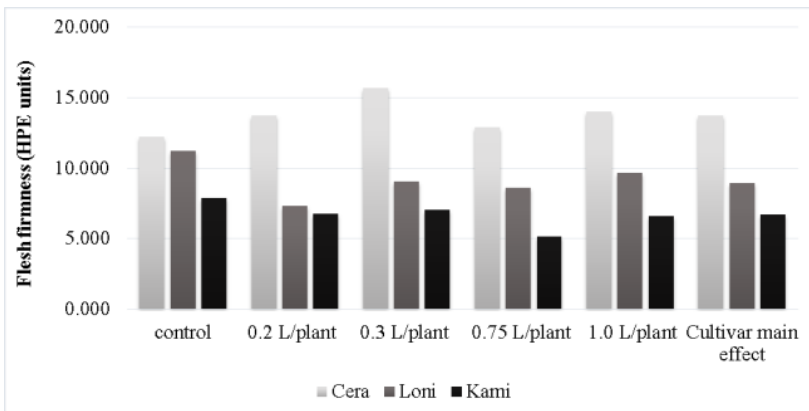

Figure 3. Cultivar influence over flesh firmness on fertilizer dose levels (Lonicera spp.)

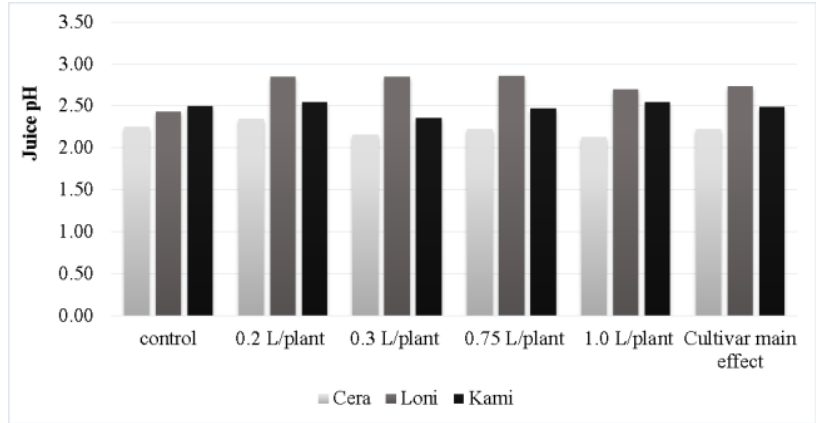

Figure 5. Cultivar influence over juice pH on fertilizer dose levels (Lonicera spp.)

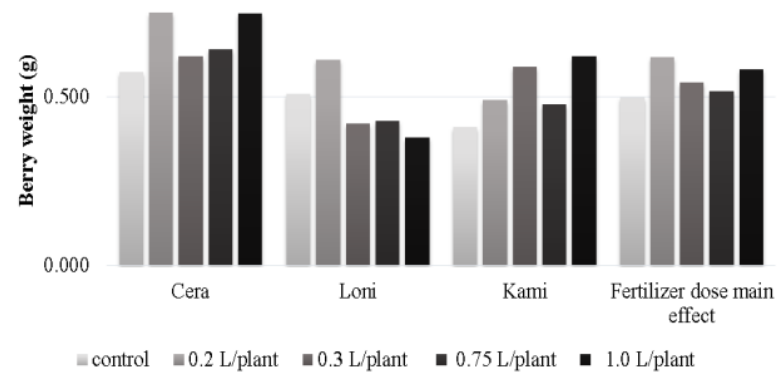

Figure 2. Fertilizer dose influence over berry weight on cultivar levels (Lonicera spp.)

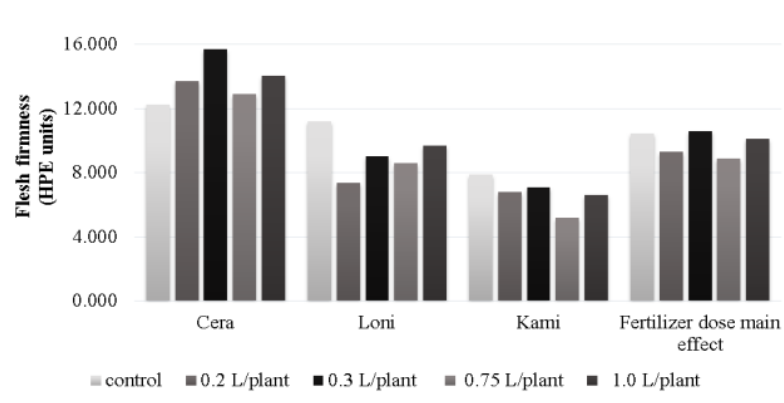

Figure 4. Fertilizer dose influence over flesh firmness on cultivar levels (Lonicera spp.)

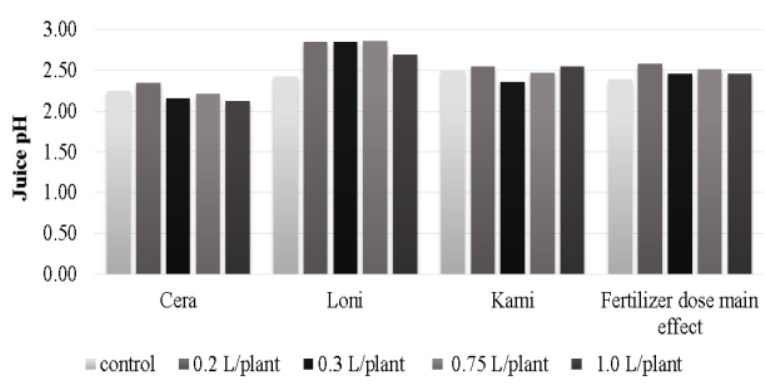

Figure 6. Fertilizer dose influence over juice $\mathrm{pH}$ on cultivar levels (Lonicera spp. 


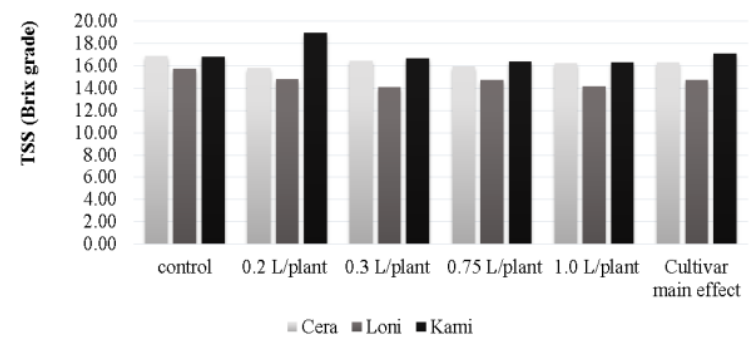

Figure 7. Cultivar influence over total soluble content on fertilizer dose levels (Lonicera spp.)

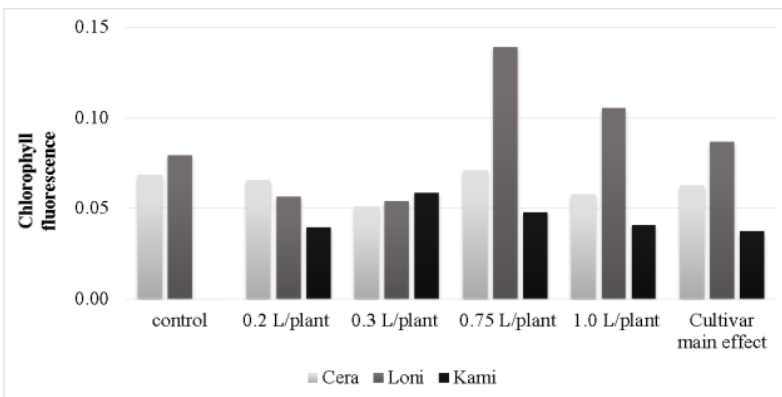

Figure 9. Cultivar influence over chlorophyll fluorescence on fertilizer dose levels (Lonicera spp.)

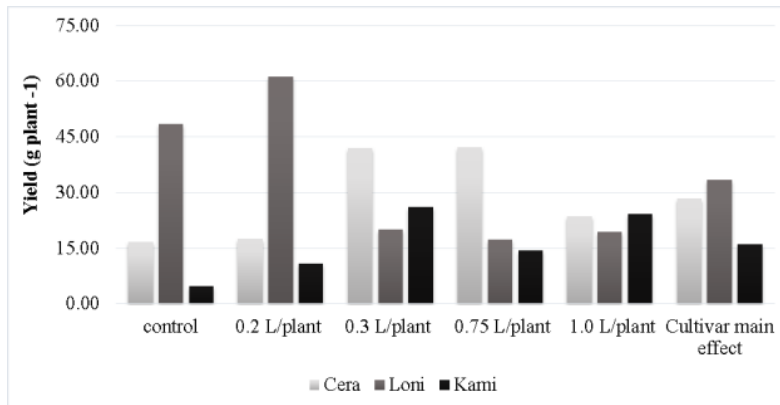

Figure 11. Cultivar influence over fruit yield on fertilizer dose levels (Lonicera spp.)

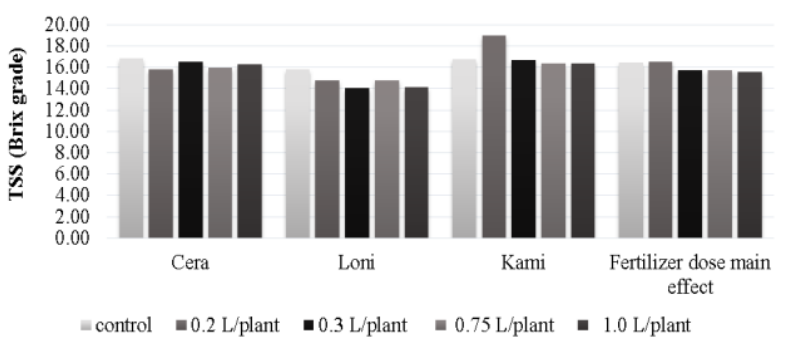

Figure 8. Fertilizer dose influence over total soluble content on cultivar levels (Lonicera spp.)

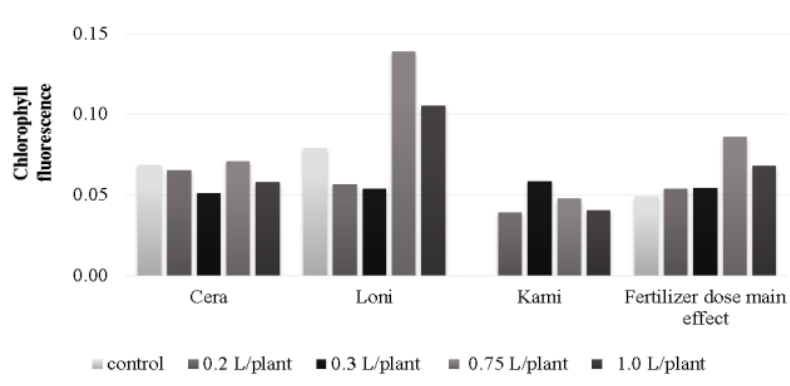

Figure 10. Fertilizer dose influence over chlorophyll fluorescence content on cultivar levels (Lonicera spp.)

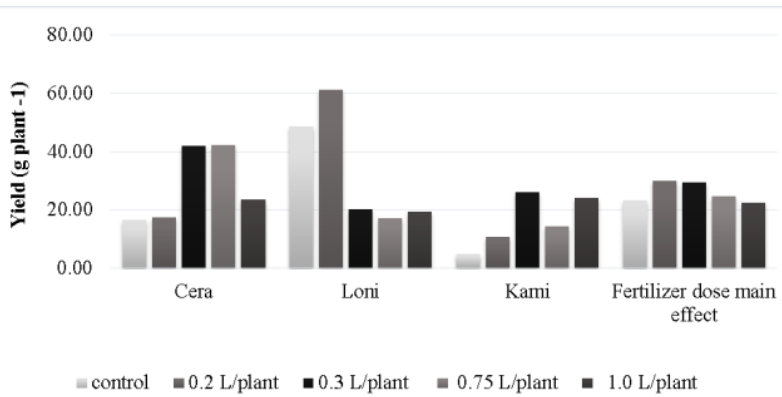

Figure 12. Fertilizer dose influence over fruit yield content on cultivar levels (Lonicera spp.

\section{CONCLUSIONS}

In the third planting year, the three cultivars significantly differed regarding fruit quality (except chromatic traits) and yield: 'Cera' was characterized by fruits with the highest weight $(0.67 \mathrm{~g})$ and firmness (13.71 units Bareiss HPE-II-FFF), 'Kami' had higher values of total soluble solids (17.09 ${ }^{\circ}$ Brix), and 'Loni' was the most productive (33.33 $\left.\mathrm{g} \mathrm{plant}^{-1}\right)$. Fertilization influenced significantly fruit weight, juice $\mathrm{pH}$, and yield. Compared to untreated plants, fertilization with vermicompost at a dose of $0.2 \mathrm{~L} \mathrm{plant}^{-1}$ stimulated the increase of fruit weight (by $14.81 \%$ ), juice $\mathrm{pH}$ (by $9.79 \%$ ), and 
fruit production per plant (by 36.65\%). The highest fruit weight was achieved for 'Cera' cultivar fertilized with vermicompost $0.2 \mathrm{~L}_{\text {plant }}{ }^{-1}(0.749 \mathrm{~g})$; the firmest fruits (15.68 units Bareiss HPE-IIFFF) were picked also from 'Cera' but in vermicompost $0.3 \mathrm{~L}_{\text {plant }}{ }^{-1}$ treatment; the less acidic fruits $\left(\mathrm{pH}\right.$ 2.86) resulted from 'Loni' when vermicompost $0.7 \mathrm{~L} \mathrm{plant}^{-1}$ was used; 'Kami' treated with vermicompost $0.2 \mathrm{~L}_{\text {plant }}{ }^{-1}$ had the highest soluble solids content $\left(18.97^{\circ}\right.$ Brix $)$ and the highest epicarp color luminosity, red and yellow pigment content. Also, 'Kami' showed the lowest chlorophyll fluorescence QY (0.00) in the untreated variant. The most productive was 'Loni' cv. under the vermicompost $0.2 \mathrm{~L} \mathrm{plant}^{-1}$ fertilization $(61.32 \mathrm{~g}$ per plant). The significant improvement in fruit quality and yield indicated that vermicompost fertilization could be successfully used for the organic culture system.

\section{ACKNOWLEDGEMENTS}

This paper was supported by a grant from the Romanian Ministry of Research and Innovation, CCCDIUEFISCDI, project number PN-III-P1-1.2-PCCDI-2017-0662, contract 12PCCDI/2018.

\section{REFERENCES}

Auzanneau, N., Weber, P., Kosińska-Cagnazzo, A., \& Andlauer, W. (2018). Bioactive compounds and antioxidant capacity of Lonicera caerulea berries: Comparison of seven cultivars over three harvesting years. Journal of Food Composition and Analysis, 66, 81-89.

Barney, D.L., Cogger, C., Fitzpatrick, S.M., Hart, J., Miles, C., Miller, T., Moore, P.P., Murray, T., Rempel, H., Strik, B., and Tanigoshi, L. (2007). Commercial red raspberry production in the Pacific Northwest. Edited by D.L. Barney and C. Miles. Pacific Northwest Extension publications.

Conesa, A., Manera, F. C., Brotons, J. M., Fernandez-Zapata, J. C., Simón, I., Simón-Grao, S., ... García-Sanchez, F. (2019). Changes in the content of chlorophylls and carotenoids in the rind of Fino 49 lemons during maturation and their relationship with parameters from the CIELAB color space. Scientia Horticulturae, 243, $252-260$. doi:10.1016/j.scienta.2018.08.030

Farooq, N.; Kanwal, S.; Ditta, A.; Hussain, A.; Naveed, M.; Jamshaid, M.U.; Iqbal, M. (2018). Comparative efficacy of $\mathrm{KCl}$ blended composts and sole application of $\mathrm{KCl}$ or $\mathrm{K} 2 \mathrm{SO} 4$ in improving $\mathrm{K}$ nutrition, photosynthetic capacity and growth of maize. Soil Environ., 37, 68-74.

Jan, A., Osman, M. B., \& Amanullah. (2013). Response of chickpea to nitrogen sources under salinity stress. Journal of plant nutrition, 36(9), 1373-1382.

Kerley, S. J. (2000). The effect of soil liming on shoot development, root growth, and cluster root activity of white lupin. Biology and fertility of soils, 32(2), 94-101.

Murchie, E. H., \& Lawson, T. (2013). Chlorophyll fluorescence analysis: a guide to good practice and understanding some new applications. Journal of experimental botany, 64(13), 3983-3998.

Podsędek, A., Majewska, I., Redzynia, M., Sosnowska, D., \& Koziołkiewicz, M. (2014). In 478 vitro inhibitory effect on digestive enzymes and antioxidant potential of commonly 479 consumed fruits. Journal of Agricultural and Food Chemistry, 62(20), 4610-4617. 480

Takahashi, A., Okazaki, Y., Nakamoto, A., Watanabe, S., Sakaguchi, H., Tagashira, Y., ... \& Chiji, H. (2014). Dietary anthocyanin-rich Haskap phytochemicals inhibit postprandial hyperlipidemia and hyperglycemia in rats. Journal of Oleo science, 63(3), 201-209.

Tremblay, C., Deslauriers, A., Lafond, J., Lajeunesse, J., \& Paré, M. C. (2019). Effects of soil pH and fertilizers on haskap (Lonicera caerulea L.) vegetative growth. Agriculture, 9(3), 56.

Zhao, X. Q., \& Shen, R. F. (2018). Aluminium-nitrogen interactions in the soil-plant system. Frontiers in plant science, $9,807$. 